\title{
sciendo
}

Current Issues in Pharmacy and Medical Sciences

Formerly ANNALES UNIVERSITATIS MARIAE CURIE-SKLODOWSKA, SECTIO DDD, PHARMACIA

\section{$p$-Synephrine and its various pharmacological effects}

\author{
Wojciech Ziemichod $^{1 \star}{ }^{\circledR}$, Ewa Gibula-Tarlowska ${ }^{2} \oplus$, Jolanta H. Kotlinska ${ }^{2} \oplus$, \\ Pawel Grochecki ${ }^{2}\left[\right.$, Ewa Kedzierska ${ }^{2}$ [อ
}

\begin{abstract}
${ }^{1}$ Student Research Group at the Department of Pharmacology and Pharmacodynamics, Medical University of Lublin, Poland
${ }^{2}$ Department of Pharmacology and Pharmacodynamics, Medical University of Lublin, Poland
\end{abstract}

\section{ARTICLE INFO}

Received 19 July 2021

Accepted 17 September 2021

\section{Keywords:}

p-synephrine,

anti-obesity activity,

anti-diabetic activity,

anti-inflammatory activity,

antidepressant activity.

\begin{abstract}
There is a number of diseases for which, scientists are constantly looking for a promising new treatments. Isolation of novel substances with biological activity from plants gives hope for its use in treatment. In this review, we focused on the biological activity of $p$-synephrine (4-(2-aminoethyl)phenol) which was previously confirmed during both in vitro and in vivo tests. The main part of the review is dedicated to the anti-obesity activity of $p$-synephrine, as obesity is a disease of contemporary civilization. However, synephrine also possesses anti-diabetic, anti-inflammatory and antidepressant activity and it is confirmed to be a hypotensive agent in portal hypertension. The review also emphasize that, based on current knowledge, the use of $p$-synephrine appears to be exceedingly safe with only limited range of side effects. Therefore, it seems that this substance may be of great importance in the pharmacotherapy of many disease states and further research is necessary.
\end{abstract}

\section{INTRODUCTION}

Synephrine belongs to the group of protoalkaloids, and was extracted for the first time from Citrus aurantium (F. Rutaceae). It is present in various amounts in most citrus species (oranges, grapefruits and mandarins), but its main source is bitter oranges. Interestingly, low levels of synephrine have been found in normal human urine [1], as well as in other mammalian tissue [2].

This compound is a member of the ethanolamines, with a substituted hydroxyl group in position 1 and a methyl group at the amino nitrogen. It occurs as isomer $p$-synephrine and $m$-synephrine. Despite the fact that $m$-synephrine bears similarity to phenylephrine, the compound does not belong to the same chemical entities. In its natural state, it is presented as isomer $p$-synephrine (also known as oxedrine or parasympatol). $p$-synephrine is approved as a medication, therefore, this review relies mainly on the description of this isomer. The chemical structure of $p$-synephrine is similar to ephedrine, which was described for the first time in 1888, and is a substance obtained from Ephedra plants. Ephedrine possesses hypertensive, adrenergic and analeptic effects. It has been used as a thermogenic agent in supplements for athletes, as well as in the treatment of hypotension. Nowadays, due to the availability of more selective compounds with safer pharmacological profiles, ephedrine

\footnotetext{
^ Corresponding author

e-mail: zimiwoj@gmail.com
}

has been withdrawn. A compound with a wide spectrum of pharmacological activity and limited side effects that can be used as a replacement for ephedrine is $p$-synephrine.

This application is related especially to the reduced lipid solubility of $p$-synephrine as compared to ephedrine, which results in low transport of this compound into the central nervous system (CNS) [3]. Moreover, structural differences ensure that $p$-synephrine exhibits little or no CNS and cardiovascular stimulation, as compared to ephedrine, norepinephrine, $m$-synephrine and amphetamine (Fig. 1).

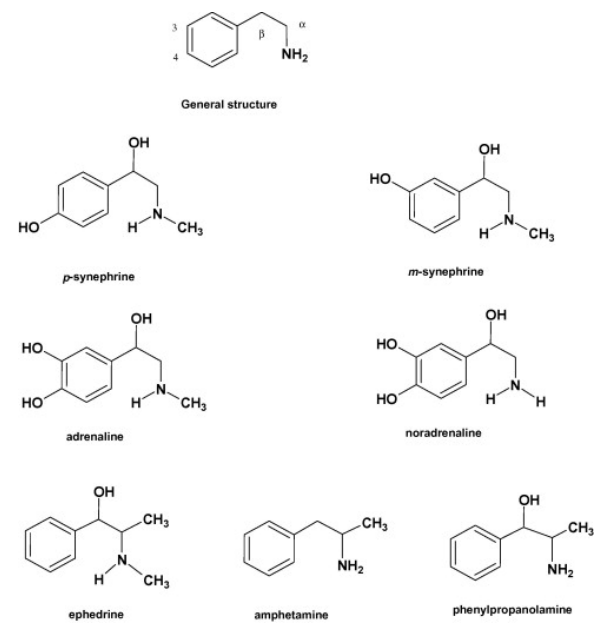

Figure 1. Chemical structures of compounds with structural similarities to $p$-synephrine [4] 
It is currently the most often used as a compound in the treatment of obesity. The compound also possesses:

- anticancer activity [5];

- anti-inflammatory activity [6,7];

- antidepressant activity [8];

- hypertensive activity [9-11];

- contraction of blood vessels [10,12];

- stimulation of glucose consumption in skeletal muscle cells [13].

Due to the increased interest in this substance, the aim of current review is to present the properties and current and possible uses of synephrine in pharmacotherapy.

\section{RECEPTOR BINDING AFFINITY}

In an evaluation conducted by Stohs et al. [12], who compared synephrine to ephedrine, $p$-synephrine and $m$-synephrine were found to be not equal as to their biological activity, as due to certain stereochemical differences, both isomers bind to receptors with different affinity. Accordingly, $p$-synephrine has lower ability to stimulate $\alpha 1, \alpha 2$, $\beta 1, \beta 2$, compared to typical sympathomimetics. Moreover, it is characterized by distinct preference for the $\alpha 1$ over the $\alpha 2$ receptors [14] and much lower potency at $\beta$ receptors (regardless of sub-type) than at $\alpha$-receptors. There is some evidence that synephrine also has weak activity at the 5 - $\mathrm{HT}$ receptors $\left(5-\mathrm{HT}_{2 \mathrm{~A}}\right.$ and $\left.5 \mathrm{HT}_{1 \mathrm{D}}\right)$, and that it interacts with trace amine-associated receptor 1 (TAAR1) $[10,12]$. Therefore, $p$-synephrine may be devoid of side effects typical for ephedrine (such as increase of heart rate and blood pressure). Furthermore, stimulation of $\beta_{3}$ receptors by $p$-synephrine can decrease diastolic blood pressure $[15,16]$. The aforementioned clearly indicate that p-synephrine, in usually used doses, shows a more favorable therapeutic profile than ephedrine [12].

\section{$P$-SYNEPHRINE AND TREATMENT OF OBESITY}

Obesity is a global problem that particularly affects both the elderly and young people, and a number of supplements have been marketed that help to lose weight. On account of the withdrawal of ephedrine-containing supplements by the Food and Drug Administration (due to a number of side effects such as increased heart rate, heart failure and hypertension), interest in $p$-synephrine, a promising agent in the treatment of this disease, is growing. According to current knowledge, $p$-synephrine can be used in the treatment of obesity because of effects such as:

- increase of resting metabolic rate and energy expenditure;

- inhibition of glucose production [17];

- thermogenic activity [18];

- influence on enzymes activity [19,20];

- lipolytic activity;

- katabolic activity;

- influence on the differentiation of beige adipocytes [4,15,21-29].

Possible mechanisms involved in these effects include its affinity to the Neuromedin U2 receptor (NMU2R). These receptors are located in the hypothalamic region which is associated with regulation of several important physiological functions such as nociception, stress response, energy balance and food intake. This claim is supported by in vitro experiments that indicated that $p$-synephrine binds selectivity with NMU2R, and, in a dose dependent manner, decreases food intake, as well as improves metabolic homeostasis [24].

During in vitro studies, $p$-synephrine was discovered also to suppress adipogenesis. The activity of the compound relies on regulation of Akt signalling pathway by reducing the expression of CCAAT/ enhancer-binding protein $\alpha$ $(\mathrm{C} / \mathrm{EBP} \alpha)$, as well as the peroxisome proliferator-activated receptor (PPAR). Subsequently, it leads to a reduction in fatty acid binding protein 4 (aP2) expression. It also was noted to inhibit glycogen synthase kinase (GSK3B). All of these mechanisms result in inhibition of fat accumulation, as well as differentiation of adipocytes, which, in turn, inhibits adipogenesis. Such effects were dose dependent [22]. The activity also included lipolytic activity. This was investigated in vitro by Mercader et al. [30]. All the received results were comparable to the effects of the typical $\beta$ receptor agonist - isoprenaline. Over all, $p$-synephrine lipolytic activity on human subcutaneous adipose cells was estimated as 33\% (compared to isoprenaline), but these effects were detected only in concentrations above $10 \mathrm{ug} / \mathrm{ml}$. In rat adipocytes, synephrine stimulated lipolysis in a dose-dependent manner.

In studies conducted in vivo using the rat's liver, p-synephrine demonstrated an ability to modify the liver metabolism. Herein, $p$-synephrine influenced glycogenolysis and increased glucose generation. Moreover, researchers noticed that glycogenolysis was stimulated not only by pure p-synephrine, but also by other compounds present in an C. aurantium extract. The scientists concluded that the most probable mechanism of both hemodynamic and metabolic effects relied on stimulation of the adrenergic ( $\alpha 1$ and $\beta 1)$ receptors present in the liver - an effect at least partly $\mathrm{Ca}^{2+}$ and cAMP related [25].

In order to advance the study of the beige adipocytes, which are believed to have a prominent role in increasing energy expenditure through differentiation, researchers evaluated the influence of $p$-synephrine on these cells. According to the study findings, $p$-synephrine increased the expression of mRNA uncoupling protein 1 (UCP1) in stromal vascular fraction (SVF) cells in a dose dependent manner, and morphological changes in beige adipocytes were observed. What is interesting, it was established that this activity relied on the stimulation of $\beta 3$ adrenergic receptors [15].

Knowing that caffeine can also increase the metabolic rate, a research team assessed its effect compared to $p$-synephrine. They established that the use of caffeine, $p$-synephrine, and a combination of these compounds increased the maximal rate of fat oxidation during exercise, as compared with a placebo, without modifying energy expenditure or heart rate. However, the coadministration of $p$-synephrine and caffeine did not present an additive effect to further increase fat oxidation during exercise. It was also confirmed again, that p-synephrine does not influence the heart rate [21].

Maldonado et al. measured in vivo, as well as in vitro, the influence of p-synephrine on hepatic enzymes activities 
in perfused liver [19]. Their work indicated that $p$-synephrine administered orally in a concentration of 50 and $300 \mathrm{mg} / \mathrm{kg}$ was able to increase the activity of glycogen phosphorylase. This subsequently improved glycogenolysis in perfused liver and caused increased glycemia in rats. It also decreased the activity of pyruvate kinase and pyruvate dehydrogenase (in both models - in vitro and in vivo), which indicates that $p$-synephrine is able to inhibit carbohydrates transformation to lipids (which is crucial in obesity treatment). It was also noticed that $p$-synephrine enlarged the hepatic pools of adenosine, diphosphate and adenosine triphosphate.

\section{INFLUENCEOFP-SYNEPHRINEONINFLAMMATION}

Several studies have demonstrated the anti-inflammatory activity of $p$-synephrine. According to the Roh et al. [6], the anti-inflammatory activity of $p$-synephrine presumably relies on inhibition of Eotaxin-1 expression (a chemoattractant factor for eosinophils). Their research revealed that $p$-synephrine acts as a signal transducer and activator of signal transduction, and, particularly is an activator of transcription 6 (STAT6), which is a relevant factor in the production of eotaxin-1 in IL-4 induced cells. This occurs by way of the inhibition of phosphorylation and translocation of these factors. As described, the inhibitory activity was dose related (the higher dose, the highest inhibition rate). While activity was measured for both isomers ( $m$-synephrine and $p$-synephrine), it turned out, the activity described above was associated only with the $p$-synephrine isomer.

The anti-inflammatory activity of $p$-synephrine was also indicated in acute lung injury in mice after lipopolysaccharide (LPS) administration. The undertaken experiments demonstrated that administration of $p$-synephrine in a dose 5 or $15 \mathrm{mg} / \mathrm{kg}$ one hour before LPS administration can significantly reduce the concentration of TNF- $\alpha$, IL- 6 and increase the concentration of IL-10 up to 48 hours. Moreover, $p$-synephrine inhibited activation of NF-Kb and lowered myeloperoxidase activity [7].

Furthermore, Arbo et al. [31] showed that in mice, $p$-synephrine induced an antioxidant and tissue protective effect by enhancing reduced glutathione content, decreasing glutathione peroxidase activity and increasing catalase activity.

\section{ANTIDEPRESSANT - LIKE EFFECT OF P-SYNEPHRINE}

The possible antidepressant effect of $p$-synephrine was evaluated during in vitro, as well as in vivo tests using $p$-synephrine stereoisomers. The behavioral experiments indicated that $p$-synephrine administrated orally decreases the duration of immobility in the tail suspension test (TST) and forced swim test (FST) in mice (dose 1-10 mg/kg). However, administration of a high dose $(30 \mathrm{mg} / \mathrm{kg})$ returned the duration of immobility to control values in both tests. Moreover, the antidepressant effect of this drug was reversed by administration of the $\alpha 1$ antagonist - prazosin [32]. Initially, these results suggested that stimulation of $\alpha 1$ receptors is involved in the above effects of $p$-synephrine. However, subsequent experiments indicated that the antidepressant activity of $p$-synephrine results from modulation of noradrenergic neurotransmission by this compound. These suggestions were confirmed in behavioral tests commonly used to screen antidepressant activity (TST and reserpine-induced hypothermia) and in vitro tests focusing on presynaptic noradrenergic systems.

In these experiments, the authors indicated that $\mathrm{R}$ $(-)-p$-synephrine evokes antidepressant effect to a lower extent than $\mathrm{S}-(+)-p$-synephrine. This is probably a result of the differential effect of the stereoisomers on the vesicular monoamine transporter. As to the influence of the release of NA from rat cerebral cortical slices, $p$-(-)-synephrine, but not isomer $-(+)$ demonstrates preferable activity.

Another interesting observation is that the U-shape dose response after administration of S-(+)-p-synephrine is possibly related to changes of balance between the noradrenaline uptake-inhibiting activity and noradrenaline release-stimulating activity after administration of different doses [8].

\section{$P$-SYNEPHRINE AS A ANTIHYPERTENSIVE AGENT ON PORTAL HYPERTENSION}

Researchers also investigated the influence of $p$-synephrine on the adrenergic receptors and blood vessels, notably its effect on portal hypertension. The examinations were conducted in vivo on rats with induced portal hypertension due to partial portal vein ligation (PVL) or bile duct ligation (BDL). It turns out that $p$-synephrine significantly reduces portal hypertension, as well as the splanchnic hyperemic state, and improves hemodynamic parameters such as portal tributary blood flow and portal venous pressure when compared to the control group. Other hemodynamic parameters were also ameliorated [11].

\section{$P$-SYNEPHRINE AS AN ATIDIABETIC AGENT}

$p$-Synephrine has been shown to have anti-diabetic effects. Herein, Taslimi et al. [20], demonstrated that $p$-synephrine inhibits $\alpha$-amylase and $\alpha$-glycosidase activity and to inhibit enzymes such as acetylcholinesterase, butyrylcholinesterase and carbonic anhydrase. The compound has also been found to affect glucose production and lipid accumulation in in vitro studies with H4IIE rat liver cells. In this study, when cells were incubated in glucose-free medium, Haas et al. observed an increased concentration of glucose. However, $p$-synephrine in a dose dependent manner (1-100 $\mathrm{uM}$ ) decreased production of this compound, as well as the level of glucose-6-pshosphatase (G6Pase) and phosphoenolpyruvate carboxykinase (PEPCK) [23]. Haas et al. also noticed that $\mathrm{H} 7$, which is an inhibitor of serine/threonine kinases PKA (protein kinase A), PKC (protein kinase C) and PKG (protein kinase G) blocked suppression of glucose production and enhanced glucose production. Furthermore, $p$-synephrine was found to not have influence upon lipid accumulation and the level of fatty acid synthase (FAS) and phosphorylation levels of 5' AMP-activated protein kinase (AMPK) and Acetyl-CoA carboxylase (ACC) [23]. 


\section{SAFETY OF P-SYNEPHRINE AND ITS INFLUENCE ON THE CARDIOVASCULAR SYSTEM}

Due to the chemical similarity of $p$-synephrine to other sympathomimetic agents such as ephedrine and phenylephrine and its common incorporation into food supplements, safety concerns have arisen. As previously stated, $p$-synephrine has lower affinity to $\alpha 1$ and $\alpha 2$, as well as $\beta 1$ and $\beta 2$ receptors compared to sympathomimetic agents. Moreover, it was acknowledged that $p$-synephrine does not cause hypertension or tachycardia.

Shara et al. [16], in seeking confirmation of the aforementioned, undertook a series of in vivo tests in which sixteen healthy persons received $48 \mathrm{mg}$ of $p$-synephrine for 15 days in a placebo-controlled, cross-over, double-blinded study. On the first day of the evaluation, the concentration of $p$-synephrine and caffeine in the participants' blood were estimated. The patients also filled in a questionnaire about their metabolism and health. It turned out that there were no significant changes in their heart rate or pressure. Nor were there any changes observed in the number of blood cells and biochemical parameters. Moreover, during the evaluation, none of the patients complained of adverse side effects. As a result, Shara et al. concluded that $p$-syneprine was deprived of stimulant and side effects in the cardiovascular system [16].

In other research involving the safety of $p$-synephrine that were conducted by Stohs et al. [26], test participants were placed into three groups. The first group received $50 \mathrm{mg}$ of $p$-synephrine, the second group - $100 \mathrm{mg}$ of hesperidin and the third group $-600 \mathrm{mg}$ of naringin. Seventy-five minutes after administration, the researchers did not notice any side effects such as an increase of heartbeat or hypertension. Also, other side effects such as headache or nausea were not observed [26].

Moreover, Deshmukh et al. [33] in assessing the safety of Bitter Orange Extract (BOE) (Citrus aurantium) standardized on $50 \%$ of $p$-synephrine, revealed that 14 days oral exposure of rats to the extract did not induce significant side effects in all administrated doses $(250,500,1000,2000$ $\mathrm{mg} / \mathrm{kg}$ ), although, in the second week after administration of doses 1000 and $2000 \mathrm{mg} / \mathrm{kg}$ of extract, the rats displayed transient signs of hypoactivity. The BOE also did not evoke any mutagenic activity in the Salmonella typhimurium reverse mutation (AMES) test [33]. In conclusion, there is no evidence to support the danger of synephrine use.

\section{CONCLUSIONS}

In this review we demonstrated the wide spectrum of biological activity of $p$-synephrine. Mostly known for its sympathomimetic activity, as a more selective agent, $p$-synephrine can replace ephedrine in some aspects. It is also deprived of analeptic activity. This speaks for safety of this compound. Because of its various mechanisms of action, great emphasis is placed on its use in the treatment of obesity. However, increasingly, attention is being paid to the numerous other beneficial effects of this substance. Therefore, it is possible that synephrine will become an eligible medication against depression or diabetes.
Table 1. Biological activity of $p$-synephrine and the method that confirmed the activity

\begin{tabular}{|c|c|c|}
\hline $\begin{array}{l}\text { Biological activity } \\
\text { of } p \text {-synephrine }\end{array}$ & $\begin{array}{l}\text { Method of evaluation } \\
\text { in vitro }\end{array}$ & $\begin{array}{l}\text { Method of evaluation } \\
\text { in vivo or ex vivo }\end{array}$ \\
\hline anti-obesity & $\begin{array}{c}\text { HEK293 cell lines } \\
\text { expressing NMU2R [24]; } \\
\text { 3T3-L1 preadipocytes cell } \\
\text { lines [22]; } \\
\text { beige adipocytes cell lines } \\
\text { from stromal vascular } \\
\text { fractions from mice [15]; } \\
\text { Perfused rat liver [19] }\end{array}$ & $\begin{array}{c}\text { rat liver }[19,25] \\
\text { randomized double-blind } \\
\text { experiments on } 13 \text { healthy } \\
\text { people }[21]\end{array}$ \\
\hline anticancer & $\begin{array}{c}\text { the human lung } \\
\text { adenocarcinoma cell line } \\
\text { A549 } 5]\end{array}$ & \\
\hline $\begin{array}{l}\text { anti-inflammatory } \\
\text { and antioxidant }\end{array}$ & $\begin{array}{l}\mathrm{NIH} / 3 \mathrm{~T} 3 \text { mouse fibroblast } \\
\text { cell line and normal human } \\
\text { fibroblasts (NHFs) [6] }\end{array}$ & $\begin{array}{c}\text { mice with LPS induced } \\
\text { acute lung injury [7]; } \\
\text { determination of oxidative } \\
\text { stress biomarkers in the } \\
\text { blood of male albino CF1 } \\
\text { mice [31] }\end{array}$ \\
\hline antidepressant & $\begin{array}{c}\text { vesicular monoamine } \\
\text { transporter [8]; } \\
\text { cerebral cortical slices [8] }\end{array}$ & $\begin{array}{c}\text { forced swim test (FST) } \\
\text { in mice [32] } \\
\text { tail suspension test (TST) } \\
\text { in mice }[8,32] ; \\
\text { reserpine-induced } \\
\text { hypothermia [8] }\end{array}$ \\
\hline $\begin{array}{l}\text { anti-hypertensive } \\
\text { in portal } \\
\text { hypertension }\end{array}$ & & $\begin{array}{c}\text { rats with portal } \\
\text { hypertension (partial portal } \\
\text { vein ligation (PVL) or bile } \\
\text { duct ligation (BDL)) [11] }\end{array}$ \\
\hline antidiabetic & $\begin{array}{c}\text { purified enzymes } \\
\text { (spectrophotometric } \\
\text { procedure) [20]; } \\
\text { H4IIE rat liver cells [23] }\end{array}$ & \\
\hline
\end{tabular}

\section{ORCID iDs}

Wojciech Ziemichód (Dhttps://orcid.org/0000-0002-4980-3926 Ewa Gibuła-Tarłowska (Dhttps://orcid.org/0000-0001-7791-0633 Jolanta H. Kotlińska (Dhttps://orcid.org/0000-0002-4178-1515 Paweł Grochecki (Dhttps://orcid.org/0000-0003-0591-3645 Ewa Kędzierska (1) https://orcid.org/0000-0002-2648-6075

\section{REFERENCES}

1. Wang R, Wan L, Li Q, Liu X, Huang Y. Chemiluminescence of synephrine based on the cerium(IV) - rhodamine B system. Luminescence. 2007;22(2):140-6.

2. Watson DG, Midgley JM, Chen RN, Huang W, Bain GM, McDonald NM, et al. Analysis of biogenic amines and their metabolites in biological tissues and fluids by gas chromatography - negative ion chemical ionization mass spectrometry (GC-NICIMS). J Pharm Biomed Anal. 1990;8(8-12):899-904.

3. Stohs SJ. Safety, Efficacy, and Mechanistic Studies Regarding Citrus aurantium (Bitter Orange) Extract and p-Synephrine. Phytother Res. 2017;31(10):1463-74.

4. Rossato LG, Costa VM, Limberger RP, Bastos Mde L, Remião F. Synephrine: from trace concentrations to massive consumption in weight-loss. Food Chem Toxicol. 2011;49(1):8-16.

5. Xu WW, Zheng C, Huang Y, Chen W, Yang Q, Ren J, et al. Synephrine hydrochloride suppresses esophageal cancer tumor growth and metastatic potential through inhibition of Galectin-3AKT/ERK signaling. Agric Food Chem. 2018;66(35):9248-58.

6. Roh K, Kim I, Kim Y, Lee M, Lee J, Jung E, et al. Synephrine inhibits eotaxin-1 expression via the STAT6 signaling pathway. Molecules. 2014;19(8):11883-95.

7. Wu Q, Li R, Soromou LW, Chen N, Yuan X, Sun G, et al. p-Synephrine suppresses lipopolysaccharide-induced acute lung injury by inhibition of the NF- $\mathrm{BB}$ signaling pathway. Inflamm Res. 2014; 63(6):429-39.

8. Kim KW, Kim HD, Jung JS, Woo RS, Kim HS, Suh HW, et al. Characterization of antidepressant-like effects of p-synephrine stereoisomers. Naunyn Schmiedebergs Arch Pharmacol. 2001;364(1): 21-26.

9. Magos GA, Vidrio H, Reynolds WF, Enriguez RG. Pharmacology of Casimiroa edulis IV. Hypotensive effects of compounds isolated from methanolic extracts in rats and guinea pigs. J Ethnopharmacol. 1999;64(1):35-44. 
10. Hibino T, Yuzurihara M, Kase Y, Tekeda A. Synephrine, a component of evodiae fructus, constricts isolated rat aorta via adrenergic and serotonergic receptors. J Pharmacol Sci. 2009;111(1):73-81.

11. Huang YT, Lin HC, Chang YY, Yang YY, Lee SD, Hong CY. Hemodynamic effects of synephrine treatment in portal hypertensive rats. Jpn J Pharmacol. 2001;85(2):183-8.

12. Stohs SJ, Shara M, Ray SD. p-Synephrine, ephedrine, $p$-octopamine and $m$-synephrine: Comparative mechanistic, physiological and pharmacological properties. Phytother Res. 2020;34(8):1838-46.

13. Hong NY, Cui ZG, Kang HK, Lee DH, Lee YK, Park DB. p-Synephrine stimulates glucose consumption via AMPK in L6 skeletal muscle cells. Biochem Biophys Res Commun. 2012;418(4):720-4.

14. Brown CM, McGrath JC, Midgley JM, Muir AG, O’Brien JW, Thonoor CM, et al. Activities of octopamine and synephrine stereoisomers on $\alpha$-adrenoreceptors. Br J Pharmacol. 1988;93(2): 417-29.

15. Takagi M, Kimura K, Nakashima KI, Hirai T, Inoue M. Induction of beige adipocytes by naturally occurring $\beta 3$-adrenoceptor agonist p-synephrine. Eur J Pharmacol. 2018;836:67-74.

16. Shara M, Stohs SJ, Smadi, MM. Safety evaluation of p-synephrine following 15 days of oral administration to healthy subjects. A clinical study. Phytother Res. 2018;32(1):125-31.

17. Cui Z, Lee Y, Lee Y, Park D. p-Synephrine suppresses glucose production but not lipid accumulation in H4IIE liver cells. J Med Food. 2015;18(1):76-82.

18. Stohs SJ, Badmaev V. A review of natural stimulant and nonstimulant thermogenic agents. Phytother Res. 2016;30(5):732-40.

19. Maldonado MR, Bracht L, de Sá-Nakanishi AB, Correa RCG, Comar JF, Peralta RM, et. al. Actions of p-synephrine on hepatic enzyme activities linked to carbohydrate metabolism and ATP levels in vivo and in the perfused rat liver. Cell Biochem Funct. 2018;36(1):4-12.

20. Taslimi P, Akıncıoglu H, Gülçin İ. Synephrine and phenylephrine act as $\alpha$-Amylase, $\alpha$-Glycosidase, acetylcholinesterase, butyrylcholinesterase and carbonic anhydrase enzymes inhibitors. J Biochem Mol Toxicol. 2017;31(11).

21. Gutiérrez-Hellín J, Del Coso J. Effects of p-Synephrine and caffeine ingestion on substrate oxidation during exercise. Med Sci Sports Exerc. 2018;50(9):1899-906.

22. Guo LX, Chen G, Yin ZY, Zhang YH, Zheng XX. p-Synephrine exhibits anti-adipogenic activity by activating the Akt/GSK3 $\beta$ signaling pathway in 3T3-L1 adipocytes. J Food Biochem. 2019;43(11).
23. Haaz S, Fontaine KR, Cutter G, Limdi N, Perumean-Chaney S, Allison DB. Citrus aurantium and synephrine alkaloids in the treatment of overweight and obesity: an update. Obes Rev. 2006;7(1):79-88.

24. Zheng X, Guo L, Wang D, Deng X. p-Synephrine: a novel agonist for neuromedin U2 receptor. Biol Pharm Bull. 2014;37(5):764-70.

25. de Oliveira AL, Comar JF, de Sá-Nakanishi AB, Peralta RM, Bracht A. The action of p-synephrine on hepatic carbohydrate metabolism and respiration occurs via both $\mathrm{Ca}^{2+}$-mobilization and cAMP production. Mol Cell Biochem. 2014;388(1-2):135-47.

26. Stohs SJ, Preuss HG, Keith SC, et al. Effects of $p$-synephrine alone and in combination with selected bioflavonoids on resting metabolism, blood pressure, heart rate and self-reported mood changes. Int J Med Sci. 2011;8(4):295-301.

27. Stohs SJ, Preuss HG, Shara M. A review of the human clinical studies involving Citrus aurantium (bitter orange) extract and its primary protoalkaloid p-synephrine. Int J Med Sci. 2012;9(7):527-38.

28. Stohs SJ, Preuss HG, Shara M. The Safety of Citrus aurantium (Bitter Orange) and its Primary Protoalkaloid p-Synephrine. Phytother Res. 2011;25(10):1421-8.

29. Wierzejska R. Dietary supplements - panacea to contemporary health problems, or the triumph of advertisement? Med Rodz. 2017; 20(2):136-42.

30. Mercader J, Wanecq E, Chen J, Carpene C. Isopropylnorsynephrine is a stronger lipolytic agent in human adipocytes than synephrine and other amines present in Citrus aurantium. J Physiol Biochem. 2011;67(3):443-52.

31. Arbo MD, Schmitt GC, Limberger MF, Charão MF, Moro AM, Ribeiro GL, et al. Subchronic toxicity of Citrus aurantium L. (Rutaceae) extract and p-synephrine in mice. Regul Toxicol Pharmacol. 2009;54(2);114-7.

32. Song DK, Suh HW, Jung JS, Wie MB, Son KH, Kim YH. Antidepressant-like effects of p-synephrine in mouse models of immobility tests. Neurosci Lett. 1996;214(2-3):107-10.

33. Deshmukh NS, Stohs SJ, Magar CC, Kadam SB. Citrus aurantium (bitter orange) extract: Safety assessment by acute and 14-day oral toxicity studies in rats and the Ames Test for mutagenicity. Regul Toxicol Pharmacol. 2017;90:318-27. 